\title{
2. Itinerancy and the Afterlife
}

Peter Jackson Rova ${ }^{31}$

\section{Abstract}

The chapter proceeds from the sense of mutual dependence that existed between rudimentary warrior-elites and specialized suppliers of prestige in archaic Greek and Indo-Iranian societies. While this tension was fraught with the danger of bankruptcy and disloyalty, it also fostered new modes of antinomian religiosity. The Greek and Vedic comparanda revolve around the notion of sacrifice as a path to fame and immortality. We catch a glimpse into such elaborate notions in a Vedic myth about three idealized craftsmen, the Robhus, who are rewarded with immortality by the gods for their ritual services. Similar notions are linked to the mythical figure of Orpheus and the sectarian ideals of purity and abstinence among Orphics and Pythagoreans in ancient Greek society. The chapter considers how such deep-rooted ritualistic conceptions inform the frame of mind characteristic of the wandering sage, including the notion of self-care.

To what land shall I go to graze my cattle?

Where shall I go to graze them?

${ }^{31}$ Large portions of this text are also found in Jackson 2016, in which I present a similar argument from a slightly different perspective.

How to cite this book chapter:

Jackson Rova, P. 202I. Itinerancy and the Afterlife. In: Larsson, S. and af Edholm, K. (eds.) Songs on the Road: Wandering Religious Poets in India, Tibet, and Japan. Pp. I5-34. Stockholm: Stockholm University Press. DOI: https://doi.org/IO.I6993/bbi.b. License: CC-BY 4.0. 
The poet of the so-called Kamnamaèzā Hāiti (Yasna 46) begins his composition in a tone of despair and isolation. ${ }^{32}$ Zara९uštra, the alleged author of the hymn, is identified in younger tradition as a prophet and founder of the Mazdayasnian religion. Nevertheless, such secondary attributions should not mislead us to consider the Hāiti (a portion of the Old Avestan Gā $\vartheta \bar{a} s$ ) as the unprecedented testimony of a proselyte. Despite its ellipses and idiosyncrasies, it is a hymn steeped in the poetics of fame and social eating.

The poet introduces himself to us as a wandering priest in search of a patron's support. Excluded from clan and community, he traverses a land of deceitful rulers, ${ }^{33}$ where the only remaining hope for future success thrives on the imagery of a still unrevealed host with good intents and gifts in plenty. ${ }^{34}$ In other words, the fact of the poet's material poverty ('having few cattle', kamnaf'suua-35) does not discount him as a spiritual bringer of prosperity. He then goes on to ponder the mutual obligations of poet and patron, bound by the stipulations of a 'contract' (mivra-) according to the model of a guest-host relationship. ${ }^{36} \mathrm{He}$ stresses the importance of exposing deceitful clients, but also points out that these are ultimately fooling themselves as they 'shall go to the bonds of deceit's captivity'. The latter theme is further emphasized in a following stanza, where the malevolent poet-priests - collectively referred to as Kavis and Karapans - are said to have 'yoked (us) with evil actions' and hence shall become 'guests in the House of Deceit forever'. This unpleasant dwelling - conceivably the infernal terminus of sinister traffickers in ritual patron-clientage stands in stark contrast to the elsewhere attested so-called garō damāna- ('House of Laudation'), the eschatological implications of which I intend to pursue further below.

32 All quotes from the Yasnas $(=Y)$ are based on the edition of the $G \bar{a} \vartheta \bar{a} s$ by Humbach et alii (I99I). I shall follow their translation as long as the interpretation does not deviate from my own. Full references to all editions and translations of the $G \bar{a} \vartheta \bar{a} s$ that have been consulted are found in the References.

$$
\begin{array}{ll}
{ }_{33} & Y_{4} 6.1 . \\
{ }_{34} & Y_{46.3} . \\
{ }_{35} & Y_{46.2} . \\
{ }_{36} & Y_{46.5} .
\end{array}
$$


In the second half of the hymn, the poet reappears in his new status as a recognized client at the court of Vištāspa. The generous patron has become a 'truthful ally for the great offering'. Both poet and patron are said to be worthy of 'fame' (or 'to be heard', frašrūidiiāiji $)$, but it is lastly only on account of the sacrificial 'fee' (or 'prize', $m \bar{\imath} \check{z} d a-$ ) - more specifically 'by means of two fertile cows' (gāunā azī) - that the latter's 'higher existence' (parāh $\left.\bar{u}-3^{3}\right)$ gets realized in the poet's imagination. The last stanza develops and derives its new meaning from the traditional Indo-Iranian genre of dānastuti ('praise of the gift'), an inserted coda through which the poet addresses his patron in praise of experienced or expected openhandedness. 39

A mistrustful reader of the Kamnamaēza the whole composition as an elaborate plea for ritual remuneration: a ritual performance designed to secure its inherent value by evoking the mysterious blessings of ritual. It is easy to perceive why the marketing of such a craft occasionally attracts scorn and incredulity. Immediate enthusiasm cannot be expected from those asked to give hard currency in exchange for delayed and intangible gifts of post-mortem elevation, let alone from those competing for the same ritual appointments. Wandering sages have thus always incurred accusations of being charlatans and malicious practitioners of magic, both in their contemporary environment and in retrospect. Hence, the Gāthic Zaraঐuštra's characterization of deceitful clients does not differ much from how his pseudo-epigraphical counterpart Zoroaster gets characterized by Plinius the Elder, namely as the inventor of monstrous impostures of magic. $4^{\circ}$ But there is more to be drawn from this game of advanced ritual bargaining than cynical conclusions.

The precarious condition of ritual vagrancy was also an incentive for being conceptually inventive. Extending and examining the meaning of ritual exchange, and doing so in a manner persuasive enough to win a patron's liking and financial support, was the ritual professional's best insurance against destitution.

\footnotetext{
${ }_{37} \mathrm{Y}_{46} 6 . \mathrm{I}_{3}-\mathrm{I} 4$.

${ }_{38} \quad Y_{46.19}$.

39 Humbach et alii I99 I, I:9 If.

${ }^{40}$ Naturalis historiae 30.I-2.
} 
As I shall try to demonstrate here, the poetic skills involved in fashioning a patron's lasting fame were contiguous with the ritual invention of transfigured immutability. I intend to show that this supposedly 'ritual' invention emerges both in the Greek and IndoIranian world out of a common tribal past, and that the new sense of self and knowledge to which it was conducive - including phenomena such as sacrificial exegesis and ascetic practices of selfcontrol - took independent share in a process much less evasive and enigmatic than theoreticians of axiality (building on Karl Jaspers' concept of Achsenzeit) have so far been prone to admit. ${ }^{4 \mathrm{I}}$

A first step towards elucidating key moments in this process is to consider the various disguises of the itinerant ritual client, both in his role of a speaking poetic subject and as an idealized projection of that same subject. The apparent realism of Zara9uštra's address in the Kamnamaèza against an inherited mythical framework of itinerant ritual specialists, the best-preserved evidence of which include traditions linked to the Greek figure of Orpheus and a triad of semi-divine travelling craftsmen addressed in Vedic poetry with a cognate appellative, the Rohus (pl. rbhávas, sg. rbbú- < PIE * $h_{3} e r b^{h_{-}}$). I first turn to the more familiar example.

\section{II}

The post-classical artistic reception of Orpheus has somewhat obscured the big picture of this complex personality in Antiquity. Apart from his roles as a wonder-working minstrel and the victim of tragic love, he was also perceived by the ancients as a founder of mysteries and the author of salvific doctrines that attracted secteristic activities all over the Greek-speaking world. While a great deal of controversy exists today as to how the concepts 'Orphic' and 'Orphism' should be properly defined and delineated, there can be little doubt that Orpheus was already being conceived as a religious authority among independent purveyors of ritual (so-called Orphics [orphikoi] or Orpheotelests [orpheotelestai]) by the late archaic period. An early witness to this emergent phenomenon is Plato.

${ }^{4 \mathrm{I}}$ Jaspers I949. 
The key passage occurs in the second book of the Republic, ${ }^{42}$ wherein Socrates engages the brothers Adeimantus and Glaucon in a conversation about the true sense of 'justice' (dikaiosýnē). A distinction is made throughout the conversation between being truly righteous and merely appearing to be so on account of commended 'rewards and reputations' (misthoùs dè kaì dóxas ${ }^{43}$ ). Such rewards may also, Adeimantus contends, extend into the poetically crafted promise of a blissful afterlife. A first example concerns two legendary figures linked to Orpheus, Musaeus and Eumolpus, who are said to 'extol' (egkōmiázō) justice, bringing their righteous benefactors down to Hades so as to let them enjoy eternal drunkenness at a symposium, whereas the unjust are buried in mud and forced to carry water in a sieve. ${ }^{44}$ Poetic 'praise' (épainos) and 'blame' (psógos) can be claimed here to falsely determine virtues and vices in terms of mere appearances. ${ }^{45}$ The ensuing passage gives an early testimony to the actual experience of itinerant 'Orphics'. ${ }^{46}$ Adeimantus complains about 'begging-priests and seers' (agýrtai dè kaì mánteis) who arrive at the doors of the wealthy - some even try to win whole cities over to their cause - with persuasive promises of atonement and purification through the arrangement of sacrificial feasts. Indulgence in the childish delight of their 'initiation rites' (teletás) is supposed to prevail after death, but those who neglect them are threatened with suffering in the afterlife. The priests and seers are said to use books by Musaeus and Orpheus from which they confusingly chant (producing 'noise', hómados). A denigration, no doubt, since adherence to doctrines encoded in privately acquired scriptures (as opposed to the public inscription of sacred law) was a sign of heterodoxy in Athens during this period. ${ }^{47}$

It is instructive to compare this deterrent account of ritual self-marketing with the explicit strategy of the Kamnamaèzā Hāiti: the bond of allegiance with an awarding patron is presented by the client as a warrant for an elevated existence, whereas breach

\footnotetext{
42 Republic 363c-365a.

43 Republic $367 \mathrm{~d}$.

44 Republic 363c-d.

45 Republic $363 \mathrm{e}$.

${ }_{46}$ Republic 364b-e.

47 Parker I996:55.
} 
of a contract on either side of the bargain is severely reciprocated in the afterlife. The repudiation of such activities on Plato's behalf should not divert attention from his own share in the same spiritual legacy, for it was apparently against those competing for similar claims to truth and deliverance - whether sophists, poets, or initiators into the mysteries - that he raised his case. The agúrtai may be accused of persuading whole cities, but what about the city that Plato envisions in the same dialogue? Is it not just another theoretical construct meant to persuade a city? A particularly telling case of Plato's Orphic inclinations, furthermore, is the Socratic account of the souls of the wise and virtuous who, purified by philosophy, arrive at beautiful abodes in the afterlife..$^{8}$ Philosophy is conceived here as a purifying way of life that secures a 'prize of contest' (âthlon) after death. We have here an obvious case of intersecting frameworks, the mutual implications of which enforces both the novelty and familiarity of the message: the celebratory context of athletic contest on the one hand, and the initiatory context of the mysteries on the other.

What, then, can the legendary appearance of Orpheus teach us about the conceptual heritage associated with his name? Let us begin with a comparatively late datum: a fresco from one of the houses on the Vicolo dell'anfiteatro in Pompeii. ${ }^{49}$ Orpheus is seen seated in the middle of the image, facing the viewer. Dressed in a long, yellow garb with a blue hem - the typical outfit of a kitharode he holds a lyre and a plectrum. Around him are seen seated or standing females, five of which are labelled as muses, and a damaged figure on a cliff in the far back probably representing Eurydice. In the foreground on the left, Heracles is seen seated on a lion-skin with his back turned against the viewer. He listens attentively to the music with his head resting on his right hand.

Clues to the narrative subtext of the scene are found in the preface to the second book of Claudianus's 'The Abduction of Proserpina' (De raptu Proserpine), which the poet dedicated to the Urban Prefect of Rome, Florentinus, during his time in office by the end of the $4^{\text {th }}$ century CE. Despite its late date, both the content

${ }^{4}$ Phaedo II4C.

49 Helbig I 868:893. 
and context of the preface allow us to identify a series of essentials in the transmission of Orphic lore. We are told that Orpheus has for a long while refused to sing, neglecting his required task, which brings the land of Thrace into turmoil. Heifers fear the lion, mountains and woods lament his silence, but as soon as the happy news of Hercules' capturing of the man-eating mares of the Thracian king Diomedes, the 'famed ivory' (nobile ebur ${ }^{\circ}$ ) touches once more the strings of the lyre. Winds and waves are stilled, Hebrus flows more sluggishly, poplar, pine, and oak are allured by his song. A crucial detail in the description is that Orpheus performs his miraculous task in a context of heroic fame. $\mathrm{He}$ is encouraged to resume his $\operatorname{art}^{5 \mathrm{I}}$ in order to extol the labours of Hercules. This circumstance has immediate bearing on the final address of the preface, in which Claudianus brings his model narrative to the fore: 'So Orpheus, so I (Claudianus); so Hercules, so you (Florentinus).' It is the fortitude of Florentinus that incites Claudianus to sing, but the mutual excellence of their labours (both the poet's and the prefect's) secures fame for them both..$^{52}$ Whereas Heracles sides with Orpheus in this scene by analogy of the patronizing aristocrat, he is recurrently seen to do so in his capacity as a prototypal Eleusinian initiate. In his capacity as initiate, the patron becomes a client of the ritual specialist, who in his turn takes over the role of the patron as a spiritual supporter of his master. Ties of patron-clientage were thus not merely hierarchical in the sense that the patronus possesed greater material wealth than his cliens, but always inherently ambiguous in the sense that the cliens had the capacity to persuade his patronus that material wealth did not automatically imply spiritual wealth. ${ }^{53}$

\footnotetext{
50 De raptu Proserpine 16.

${ }^{5}$ De raptu Proserpine 29.

52 De raptu Proserpine 5 $\mathrm{I}-52$.

53 I will henceforth consider such relationships according to the familiar model of plebeians and patricians operating within systems of servitude in ancient Roman society. Ties of patron-clientage were usually hierarchical in the sense that the patronus possessed greater wealth than the cliens. The patronus was the benefactor of the cliens, who in his turn was expected to offer his services to the patronus. The English word 'client' - in its developed sense of someone who rather uses the service of a professional - can be said to reflect a relation that is always inherently reciprocal. As will become
} 
It has sometimes been misleadingly claimed that Orpheus is a singer not of kleós, but of pénthos ('grief'). Quite on the contrary, the intangible force by which to extoll fame was not just meant to honour the living; it was also the force thought to keep them alive after death. The theme of fame is no less present in epinician poetry than in the so-called 'dirges' (thrênoi) composed by Pindar and Simonides alike. Furthermore, the concept of a song that mysteriously moves the world to such an extent that it beguiles death ${ }^{54}$ seems indistinguishable from the concept of undying fame that the same poets developed in a tradition said to ensue from Orpheus, the 'father of songs' (aoidân patêr). ${ }^{55}$ Although Orpheus is absent from Homeric epic, the extant traditions associated with his name in post-Homeric lore are likely to reflect an ancient melic genre that was perhaps already considered distinct from the topics of epic song by the poets of the Dark Age. ${ }^{56}$ In its developed melic sense, as it were, a hero's kleós could be conceived as áphthiton ('undecaying') and ásbeston ('inextinguishable') according to the same logic of privation - that is, irresistable to forgetfulness in a poet's memorable song - as its philosophical continuator was thought to be 'uncausing forgetfulness', alêtheia (Doric alátheia).

Poets and sages in the late archaic period have been variously assumed to associate the non-local substance of all that appears

apparent in the following pages, the role of the ritual client may lend some of its social characteristics to the patron. In his role as initiate, the patron becomes the client of the ritual specialist, who in his turn takes over the role of the patron as a spiritual supporter of his master.

54 Euripides, Alcestis 357-59.

55 For example, Pindar's Pythian 4.I76.

${ }_{56}$ In addition to the distinction between an archaic Orphic/melic and a Homeric/epic tradition, Wilson (2009:55-56) makes the following perceptive remark regarding Thamyris the Thracian, an apparent representative of Orphic ('melic') lore avant la lettre: 'If we ... admit the possibility that Thamyris in the Iliad may have presented a tradition of religious song that proferred the hope of an afterlife radically different from that implied by the Iliad, the passing story of his encounter with the Muses takes on a very different character. ... Like Orpheus, Thamyris was not merely a rival to the singers of Homeric poetry, or to their authority-figures in myth, be they an archetypal Homeros, or the Muses of Olympos. Early music and poetry did not form an autonomous sphere of artistic excellence and competition. Differences in music implied differences in world-view, and in particular, in religious outlook.' 
and disappears with an indestructible force of mind and memory, whether stable or ever-flowing, that clearly hearkens back to the tradition of poetic praise. Simonides perhaps came closest to linking these concepts together. Firstly, in his eulogy to those who fell at Thermopylae, wherein the Spartan king Leonidas is said to have left behind an 'ever-flowing glory' (aénaón ... kléos ${ }^{57}$ ) an epithet of kléos likewise employed by Simonides' Ionian contemporary Heraclitus. ${ }^{8}$ Secondly, by treating 'valour' (aretế) and 'inextinguishable glory' (ásbeston kléos) as the intangible forces by means of which the dead are brought back 'from the house of Hades' (dômatos ex Aídeố ${ }^{59}$ ). Finally, in an isolated fragment virtually rephrasing Heraclitus' aphorism 'a nature tends to hide' (phýsis krýptesthai phile $\left.\hat{\imath}^{60}\right)$ : 'appearance even constrains truth' (tò dokeîn kaì tàn alátheian biâtai ${ }^{61}$ ). The constitutive force of nature is likewise the undying principle of truth beyond fleeting appearances.

In addition to being considered a father of songs, Orpheus was thought to embody the very principle of undying fame by virtue of his name. He was the one 'with famous name' (onomáklytos ${ }^{62}$ ), that is, both a provider and receiver of the gift that made him a prototype of his guild. His inert strangeness and propensity to leave and reappear, moving disruptively from city to city, was a feature that he shared with the god most strongly tied to his name and alleged country of origin: Dionysos, the veritable 'stranger within'. ${ }^{63}$ It was also a feature that he shared with the first Greek philosophers, both the truly itinerant ones (such as Xenophanes) and those merely metaphorically 'roaming' (plânē) so as to challenge commonsensical wisdom (as in the case of Socrates). Their concept of immutable truth and excellence no longer served the sole purpose of ritual persuation, but had begun to gravitate towards a new sense of politics. The true philsopher of the new polis must

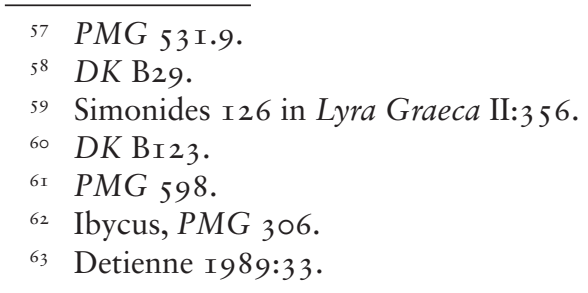


begin his precarious career as a figure of ridicule. Steering beyond the hyperboles of local politics with his cosmoplitics, he is allegorized by Plato as a 'star-gazer and babbler' ${ }^{64}$ of little apparent use to the self-indulgent citizen. A contrast is created through such an imagery between a local politics of civic pretence and a global politics of antinomian attention. However, the transgressive and subversive aspects of the latter will merely appear threatening from within the bounds of the temporary pact, whereas the travelling supplicant carries a message of otherworldly liberation.

\section{III}

Simplistic solutions to the puzzle of Orphic origins have typically consisted in taking the foreign appearance of Orpheus in ancient art and literature at face value. His appearance in myth is thus reduced to the distorted version of a real-life Thracian 'shaman', whose foreign ways earned him the reputation as seer and magician, and the salvific doctrines associated with his name to some alien substance sprung from an exotic (whether Thracian, Phrygian, or Iranian) source. Such habits of theoretical procrastination deflect attention from the inner dynamics of ritual life and mythical imagination. Greek religion owed much of its peculiarity to the symbolic vacillations between 'foreign' (xeinos) and 'homely' (oikeîs) aspects of life, between gods who arrive and those already at home. If the citizens of Athens or Thebes conceived Dionysus as the personification of a liberating force arriving from the outside, it was not because the god was an import, but because these were his inherent characteristics. He was, in Walter Otto's wording, 'the god who arrives' (der kommende Gott). The inherent strangeness of Orpheus would make equal sense in this regard. His exotic Thracian appearance could be perceived more loosely as a sign of eccentricity, sufficient to mark out the itinerant client's aptitude for ritual innovation. Evidence of this original ('pre-Thracian') trait can be obtained by considering the etymology of the proper name, which links the secondary appearance of Orpheus in Greek myth to a native tradition of considerable depth and consistency.

${ }^{64}$ Republic 488e-489a. 
The Greek name is likely to have developed from an inherited Proto-Indo-European (PIE) noun $\left(<* h_{3} r b^{b} e ́ u-\right)$ retained in Vedic rbhú- to denote a '(skilled) craftsman' ( $\rightarrow$ 'ritual specialist'). ${ }^{65}$ The complex semantics of the underlying verbal stem can be traced through its usage in Anatolian, were it expressed the quality of someone (or something) voluntarily moving between different groups: the case of a domestic animal that voluntarily 'strays' (barapta) into another fold, thus implying the specified sense 'change herds', or of deities asked to 'ally themselves' with their human hosts in a cultic context of commensality ('Come, eat and drink! Ally yourselves with me! [nu=mu=ššan barapdumati]'). The quality of moving between different groups (in search of a new ally) makes a feasible semantic basis of the Vedic noun rbhú-. It may originally have signified any kind of travelling professional, but, as suggested by the secondary adjectival sense 'skillful, ingenuous' (seen in Vedic ŕbhva-, from a virtual ${ }^{*} h_{3} r b^{b}-u-O-$, and rbhvan-, 'the skilled one', PIE $\left.<* h_{3} r b^{b}-u-o-n-\right)$, especially recalled the 'fashioning' (PIE $\sqrt{ } * t e t k$ ) skills of a carpenter.

The definite uncovering of Orpheus' pre-Greek past hinges on the identification of a proper noun ${ }^{*} H_{3} r b^{b}$ éus that developed (supposedly in late-PIE) from an honorific title, 'the ${ }^{*} h_{3} r b^{b} e$ éus par excellence', '(he) who excels in wondrous crafts', or something equivalent. Both the noun and the proper noun appear side by side in Rgveda $(=R V)$, the earliest collection of ancient Indian (or Vedic) poetry, with the developed adjectival sense still attached to the noun, while Greek evidence merely leaves us with an opaque proper noun. Unlike Orpheus, however, Vedic Robhu does not operate alone. Rather, he is conceived as the leading member of a triad, the so-called Robhus (plural rbhávas), whose mythical deeds and characteristics prompted the poets of the Rgveda to contemplate and advertise the achievements of their own guild. Just like Orpheus in his capacity as the fountainhead of melic poetry, the Robhus are represented as prototypes of the ritual clientele. It will thus prove suggestive to examine the parallel lives of Orpheus and

${ }_{65}$ I am proceeding here from Michael Estell's (I999) re-opening of the case of Greek Orpheus and Vedic Robhu. A full account of the issue is found in Jackson 2016. 
the Robus in pursuit of the real-life concerns that fostered such mythical extrapolations.

Prime events in the Rohus' mythical biography are the five canonical deeds of excellence for which they became famed and attained immortality: (I) multiplying Tvașțar's soma cup into four, (2) fashioning the chariot (sometimes said to belong to the Aśvins), (3) fashioning the fallow bay horses of Indra, (4) fashioning a cow (carving it up or making it to give milk), and (5) rejuvenating their parents. The following verse provides a summarizing moral of the five deeds:

The sons of Sudhanvan [= the Rbhus] rose to immortality by applying themselves to their labors, ritually acting well by good ritual action. ${ }^{66}$

The wondrous deeds themselves suffice to suggest that the crafts of the Robhus were modelled after ritual acts. In less specific terms, the three brothers are also said to 'have fashioned sacrifice' and themselves to be 'seeking fame among the immortals' (ámartyesu śrava ichámānāh). ${ }^{67}$

While the Vedic poets apparently represented the Robus as idealized members of their own guild, they were also keen to emphasize the Robus' divinely authorized promotion to permanent members of the divine community. This change of status also meant that they could appear in the roles of patrons receiving priestly praise. In so far as the Rbhus can be understood to impersonate ideals pertinent to any priestly lineage, we need to consider the possibility that the triad's eponymous 'change of allegiance' also echoed the ritual client's innate propensity to surrender his current patron and seek out a more beneficent ally.

There is another story hinted at in some of the hymns that appears particularly relevant. It may be referred to as the 'Story of the Rohus and Agohya', but it should be kept in mind that Agohya (literally 'Unconcealable') may be just another appellation of a more familiar figure, namely the god Savitar (literally 'Impeller'). By comparing these stanzas, we may single out four

\footnotetext{
${ }_{66} R V 3.60 .3 \mathrm{c}-\mathrm{d}$.

${ }_{67} \quad R V$ I.IIO.5.
} 
significant moments in the storyline: (I) The Robhus wander about in search for custody; (2) they arrive at the house of Agohya/ Savitar and enjoy his hospitality; (3) they sleep in the house of their host for either twelve days or a whole year; (4) during (or in direct adjacency to) this transitional state, they exert the force of their wondrous skills on nature.

In sudden recognition of his 'own comrades', the poet Kutsa imagines the former situation of the Rohus by analogy with the present hardships of unemployed poet-priests. The theme of the distressed vagrant ('in search of [pl.] daily bread', ābhogáyam ... ichánta) is thus employed by the poet to fulfil his own hope for future immortalization (we noticed earlier how the poet of the Kamnamaèza Häiti recalled his former calamities on the road as a foil for his eventual rise to excellence at the court of Vištāspa):

When, [both in East and West,] you went forth in search of your daily bread, as certain comrades of mine, o sons of Sudhanvan, after your fill of roaming you came to the house of Savitar the pious. ${ }^{68}$

The next stanza informs us that Savitar, in accordance with the impelling power inherent in his name, 'impelled [them] to immortality' (amrtatvám ásuvad). The reason for their promotion is, however, not explicitly stated. They went, it simply says, 'to make Agohya heed'. We need to consult other hymns in order to learn more about the Robhus' laudable service at Aghoya's. One cryptic stanza apparently refers to something the Robhus did while asleep. Another stanza seems to hint at the same event, but provides more explicit information as to what might be implied by their deeds:

When [the Robus enjoyed the hospitality] of Agohya [for twelve days] sleeping (there), (then) they made the fields good and led the rivers; plants arose upon the dry land and waters upon the low ground. ${ }^{69}$

\footnotetext{
$68 \quad R V$ I.IIO.2.

$69 R V$ I.I6I.I2.
} 
Through these wondrous deeds, performed during sleep, the Rohus apparently prove themselves worthy of immortalization because they are already behaving like immortals.

While the details of the total message escape us, it seems clear enough that the notion of Agohya's/Savitar's residence is supposed to represent an idealization version of the good patron's house. The Robhus arrive at the paradigmatic 'house of the pious' (dāśúșo $\left.g r h a^{-7^{\circ}}\right)$, they are said to enjoy the hospitality of their host, ${ }^{7 \mathrm{I}}$ and to make him heed. ${ }^{72}$ In the case of Agohya's house, however, the paradigmatic scenery has been refurnished to evoke that of a divine dwelling. The god is no longer imagined as a temporary guest, but as a host providing shelter for his cultic servants. Solar thematics were possibly added to the scenery in order to emphasize the fact of the Robhus' imminent ascent and immortalization. By such intensified degrees of imagination, the ordinary homestead in which the priest sought refuge was always a potential domicile of cult, a virtual locus of transfiguration, and, ultimately, a stepping-stone to the celestial abode of the gods. Whenever a travelling poet-priest arrived at a new house, such enhanced means of expressing the hope for a mutually prosperous coalition between patron and client no doubt came in handy.

\section{IV}

There are obvious comparative benefits to be drawn from this Vedic excursus. Just like his namesakes in the Rgveda, Orpheus performs transfiguratively, that is, not merely by relating a topic of song, but by mysteriously moving nature on a par with a divinity: the song begins to conjure that of which it sings. An example is the fragment from Simonides, ${ }^{73}$ according to which countless birds are said to fly over Orpheus' head and fish jump straight out of the sea in accordance with his beautiful song (kalâi sỳn aoidâi). This early testimony reflects Orpheus in a role once indistinguishable from that of the quasi-historical mystagogue. In his

\footnotetext{
$70 \quad$ RV I.IIO.2.

${ }^{71} \quad R V 4 \cdot 33 \cdot 7$.

${ }^{72}$ RV I.IIO.3.

73 PMG 567.
} 
joint role of a prototypal wandering singer, inventor, and initiator, he is the ultimate Jack-of-all-trades. By tuning the cosmos to his all-embracing organon, he excels in a craft lacking in immediate gain, yet rhetorically equipped to supersede all other crafts through its power over matter and mortality. His example belongs to a narrative framework within which the promulgations of latter-day religion and rarefied autotelic art had not yet begun to develop distinctive features of their own. It is also within this framework that one must seek the eschatological foundations of the philosopher's 'way of life' (bios). As we already saw, the distinctly ritual notion of a life in purity - of ending up 'purified' (kathērámenos) in a 'pure dwelling' (katharà oíkēsis) 74 - was a legacy shared between Plato and his contemporary Orpheotelests. It traces a discourse impelled by the existential concerns of ritual specialists in a distant tribal past, structured around the prize and lasting value of ritual, and ultimately designed to accommodate a life perfectly at rest in its state of being thus ritually informed.

Gāthic poetry, once again, clearly testifies to the early pertinence of such a discourse. In addition to the above-mentioned thematic of the Kamnamaèzā Hāiti (Y 46 ), Zaraঐuštra's eschatological intimations are centred around a fixed figure of speech that brings the theme of laudation to the fore: garo damāne (or damāne garō). The figure combines two transparent Indo-Iranian nouns (the familiar term for 'house' and a noun meaning '[song] of praise, welcome' [gar-]) to suggest something like 'in(to) the House of Laudation' ( $-\bar{o}$ and $-\bar{e}$ are clearly genitive and locative markers). The song of praise was a gesture of welcome enacted in typical guest-host situations, on which cultic invocations and invitations of the gods were modelled.

An eschatological interpretation of the Gāthic garō domānahas been endorsed by many influential Iranists. H. S. Nyberg, in his comprehensive treatise on Iranian religion from I938, concluded that the garō domāna- was the heavenly dwelling towards which the hymns of praise ascended. He argued that it was through the mediation of Ahura Mazdā's 'thought' (manayhā [instr. sg.]) and the poet's 'songs of praise' (garōbīš [instr. pl.]

74 Phaedo II4c. 
stütam) that the 'sacred actions of humans' were brought up to that place.

Consider, for instance, the following stanza from the last hymn in the fourth $G \bar{a} \vartheta \bar{a}$ :

What prize ZaraЭuštra

previously promised to his adherents, into that House of Laudation [did the Wise] Lord come as the first one.

Through good thought these (offerings) are committed to You, and to Truth, with benefits. ${ }^{75}$

It is conceivable that the notion of the 'House of Laudation' occurred to the poet and his auditor, not just as a house in which praise is sung, but as a dwelling forged by the poet's song. Ahura Mazdā enters into it 'as the first one' by first being subjected to poetic praise, and it is along the same itinerary that the openhanded patron will finally receive the reward of joining his supreme lord as a guest.

Could a poetic invention such as the House of Laudation perhaps be considered an enhanced projection of the poet's present locus of performance? Was the poet in fact modelling his prospect of a happy afterlife after the solemn occasion in his master's house, imagining the patron to be sitting once again among his gods, once again becoming the subject of praise alongside his gods? Such conjectures do merit consideration in view of the hints supplied by other traditions. ${ }^{76}$ In any case, there is ample

\footnotetext{
${ }^{75}$ Y 5 I.I5.

${ }^{76}$ I can think of no better indicator of such a poetic strategy than the notion of Valhọll ('the hall of fallen heroes') in Old Norse poetry, which clearly emulates the festive occasion in the guest-hall of the chief. Such events were not only popular topics of epic song - as seen, for instance, in Beowulf - but the typical setting of their performance. The epic strategy of the paradigmatic banquet usually marks a turning point in the storyline, but it can also function as a window on other topics of song - much in the style of the classical rhetorical figure known as ékphrasis - through the medium of the imaginary bard in the hall. The banquet represents an idealized image of social intercourse according to the expected standards of good food, plenty of drink, and poetic performance. For an exhaustive treatment of Valholl in Old Norse poetry, prose, and iconography, see Dillmann in $R G A 35$ [s.v. Valhọll]).
} 
evidence in the $G \bar{a} \vartheta \bar{a} s$ of a contiguous relationship between the poet's praise and the patron's happy afterlife.

Offshoots of a similar development in Greek culture likewise appear in contexts of poetic praise. But similar eschatological motives, in their proper encomiastic context of lyric poetry, are also seen to inform philosophical self-understanding. Plato, in the Phaedrus, evokes a region above the heavens with which true knowledge is concerned. It is a region that, unlike (yet still by analogy with) those 'sung by the poets' (bymnēsé tôn poiètès), presents itself to the sole receptacle of the mind's eye as a colourless, formless, and intangible 'plain of truth' (alètheía pedión). ${ }^{77}$ Philosophical truth-seeking is characterized here by at once interrupting and dissimulating a poet's technique for fashioning a patron's lasting fame. If the latter appeals to a ludic spirit of local self-confidence, however, the former requires the dismantling of accepted experience by directing the mind towards a solid state of true being.

The philosopher and the encomiast would seem to have little in common had it not been for the ritual legacy that so neatly ties them together. It is this deep-seated legacy that I have sought to unravel here by indicating how the predicaments of ritual professionalism gave incentive to new means of ontological reasoning. It was arguably, and ironically, among itinerant traders in ritual, decisively in need of what they persuasively sought to create, that the notion of a life at rest in deathless purity received its most pregnant formulations.

\section{V}

The area from which the Mazdayasnian religion supposedly spread - the old land known to the Greeks as Arachosia - was one of the first to witness a confluence of ascetic currents that had emerged independently in India and Greece during the mid-I ${ }^{\text {st }}$ millennium BCE. Centred around itinerant sages, such as Pythagoras from Samos in the West and Gautama Buddha in the East, they mark out the first historically tangible sects and schools of philosophy to challenge the established ways of reli-

77 Phaedrus 247c-248b. 
gious life. By 'established ways' I aim broadly, on the one hand, at various forms of public worship in the Greek city-states and, on the other, the traditional ('Vedic') ritual system that thrived on the mutual commitments of priestly lineages and local warrior-elites in Indo-Aryan society. The renegotiation of such prescribed forms of ritual life would come out quite differently depending on the periods and parties involved: in some cases by causing violent uprising and civic antipathy (as exemplified by the anti-Pythagorean revolts in Magna Graeca, and public attitudes toward the so-called 'bacchanalia sacrilege' in Rome), in others by gaining support in imperial policies (as exemplified by Aśoka's and Theodosius' decrees against animal sacrifice). Especially relevant to the understanding of this dynamic, however, is that it occurred in parallel among groups who initially would have had only vague notions about each other. Nevertheless, when Greeks became more permanently exposed to Indian culture in the settlements established by Alexander the Great and the Seleucids, they seem to have conceived the antinomian lifestyle of wandering ascetics as a sign of recognition. The terms unambiguously used in the Greek and Prakrit versions of Aśoka's edicts ( ${ }^{\text {rd }}$ century BCE) to capture such circles of like-minded wanderers (Greek diatribé, Prakrit pāsamda) indicate social phenomena that had long been familiar to Greeks and Indians alike. So strong were the ascetics' similarities in appearance and outlook that writers from the Roman-Hellenistic period even considered Greek philosophers, such as Pythagoras and Democritus, to have come under the direct influence of the 'naked wise men' (gymnosophistaí) of India long before the campaigns of Alexander.

Contrary to such views, I feel confident that the ritual legacy shared between speakers of Greek and Indo-Iranian may give us sufficient cues for attributing such secondary similarities to the social forces inherently at work within these communities. It was a legacy that these speakers, in enduring unawareness of each other and their common linguistic ancestry, would have claimed as their own, but one that we are now able to retroject into the prehistoric past of Indo-European pastoral societies. Exerting its influence long after the migrations out of the Pontic-Caspian steppes, it remained a characteristic means of communication between aspiring warrior-elites and professional suppliers of 
ritual in archaic Greek, Iranian, and Vedic societies. If we can accept that this social formation had already developed some of its rudimentary characteristics in a long-lost tribal past, it becomes less of a bewilderment to imagine the parallel moves toward its gradual reformation.

\section{References}

Detienne, Marcel. 1989. The Cuisine of Sacrifice Among the Greeks. Translated by P. Wissing. Chicago: University of Chicago Press.

$D K=$ Diels, Herman \& Kranz, Walther (eds.). Die Fragmente der Vorsokratiker. Zürich: Weidmann, I996 [Reprint of the $6^{\text {th }}$ ed. I95 I-I952].

Estell, Michael. I999. “Orpheus and Robhu Revisisted”. In: Journal of Indo-European Studies, 27 (3-4), 327-334.

Helbig, Wolfgang. I 868. Wandgemälde der vom Vesuv verschutteten Städte Campaniens. Leipzig: Breitkopf und Härtel.

Jackson [Rova], Peter. 20I 6. "The Arrival of the Clients: Technologies of Fame and the Prehistory of Orphic Eschatology". In: Historia Religionum: An International Journal, 8, I69-I94.

Jaspers, Karl. I949. Vom Ursprung und Ziel der Geschichte. Munich: R. Piper \& Co. Verlag.

Lyra Graeca: Edmonds, J. M. I924. Lyra Graeca. II. Harvard, Mass.: Harvard University Press.

Nyberg, H. S. 1938. Die Religionen des alten Irans. (Reprint I966.) Osnabrück: Otto Zeller.

Otto, Walter. 1933. Dionysos: Mythos und Kultus. Frankfurt am Main: Vittorio Klostermann.

Parker, Robert. I996. Athenian Reiligion: A History. Oxford: Oxford University Press.

PMG = Page, D. L. I962. Poetae Melici Graeci. Oxford: Clarendon Press. 
$R G A=$ Hoops, Johannes et alii. 1973-2008. Reallexikon der germanischen Altertumskunde. Berlin and New York: Walter de Gruyter.

$R V=$ Rgveda: van Nooten, Barend A. \& Holland, Garry B. I994. Rig Veda: A Metrically Restored Text with an Introduction and Notes. Cambridge, Mass.: Harvard University Press.

Geldner, Karl Friedrich. 194 I. Der Rig-Veda: Aus dem Sanskrit ins Deutsche übersetzt. I-III. Cambridge, Mass.: Harvard University Press.

Jamison, Stephanie W. \& Brereton, Joel P. 20I4. The Rigveda: The Earliest Religious Poetry of India. Oxford: Oxford University Press.

Wilson, Peter. 2009. "Thamyris the Thracian: The Archetypal Wandering Poet?” In: Hunter, Richard \& Rutherford, Ian (eds.), Wandering Poets in Ancient Greek Culture: Travel, Locality and Pan-Hellenism. Cambridge: Cambridge University Press, 46-79.

Y = Yasna: Humbach, Helmut \& Elfenbein, Josef \& Skjærvø, Prods O. I99I. The Gäthās of Zarathushtra and the Other Old Avestan Texts. I: Introduction, Text and Translation; II: Commentary. Heidelberg: Carl Winter.

Kellens, Jean \& Pirart, Eric. I988-I991. Les textes vieil-avestiques. I: Introduction, texte et traduction; II: Répertoire, grammatiqaux et lexique; III: Commentaire. Wiesbaden: Dr. Ludwig Reichert Verlag.

Insler, Stanley. I975. The Gāthās of Zarathustra. Téhéran-Liège: Édition Bibliotèque Pahlavi. 